This is the peer reviewed version of the following article:

Lo Bianco, Joseph (2014) Domesticating the Foreign: Globalization's Effects on the Place/s of Languages. The Modern Language Journal, 98(1), pp 312-325, which has been published in final form at doi: 10.1111/j.1540-4781.2014.12063.x. This article may be used for non-commercial purposes in accordance with Wiley Terms and Conditions for Self-Archiving.

\title{
Domesticating the Foreign: Globalization's Effects on the Place/s of Languages
}

\section{Joseph Lo Bianco}

\begin{abstract}
Foreign language education is deeply affected by globalization, destabilizing some of the central ideas that have helped form national languages, and, by contrast, foreign languages. This article traces the economic origins of contemporary globalization and the deep communication effects that arise. Migration of peoples, instantaneous communication technologies, and new modes of imagining relationships in the context of vast flows of population, ideas, goods, and communication mean that teachers of different languages need to make multilingual and multicultural realities, rather than national and foreign ones, central notions in curriculum, teaching, and language choice. Professional dialogue between teachers of English, traditional foreign languages, heritage/community languages, and other categories of language interest are required to foster a new overall understanding of the enterprise of language education, suited to the altered world context of contemporary globalization.
\end{abstract}

Keywords: globalization; foreign languages; global English; nationing; language categorization; decolonization

Language education is profoundly affected by the "widening, deepening and speeding up of worldwide interconnectedness" (Held et al., 1999, p. 2), which constitutes globalization. Even as some scholars from its originating disciplines of international relations and realist political philosophy write postmortems for globalization theory (Rosenberg, 2005), in the domains of culture and communication interconnectedness continues to widen, deepen, and accelerate, with subtle effects on language education and dramatic effects on language policy. According to Blommaert (2010), "the processes we call globalization are not new in substance, they are new in intensity, scope and scale" (p. 1), meaning that globalization has multiple manifestations (Appudurai, 1996) and previous histories (Hopkins, 2002). As a result, there are various unintegrated ways of understanding the notion and scope of globalization. The present article focuses on one small effect of interconnectedness: the term foreign, which qualifies language, as in the teaching of foreign languages, as an issue that, however small, distills some key aspects and effects of interplay between language education and globalization.

The discussion addresses cultural effects and meanings of what is foreign about a language, and ways in which globalization destabilizes the assumptions we make as a result of seeing languages as foreign. Whole edifices of curriculum, teaching practices, and policies for language teaching are constructed on the assumption that entire languages can be considered foreign, with pervasive repercussions in curriculum, program design, and pedagogy. A central part of the argument concerns the spatial distribution of languages, the result of centuries of effort by states, national and pre-national alike, to organize who speaks what where, conducted through overt and covert strategies of language planning (Lo Bianco, 2010b).

The article also poses the question of the pedagogical and policy consequences that flow from problematizing the foreignness of foreign language teaching. The term foreign relativizes language and space, so that particular geopolitical spaces, constituted as national states, are dedicated exclusively or dominantly to standard forms of particular languages, and are differentiated from neighboring or distant geopolitical spaces dedicated to different languages. Language education 
internal to national states has aimed at reinforcing and naturalizing selected linguistic codes, so that what is constituted as foreign is counterposed to what is constituted as familiar. But while domestic policy of national states has mostly sought to homogenize populations, security and economic interactions have persisted across political boundaries, meaning that domestic processes of vertical linguistic consolidation (bolstering national languages) have gone hand in hand with horizontal processes of foreign language education. Globalization is steadily rupturing this order, exposing its historical specificity, posing new challenges for language education, both education in national languages for native speakers and, the focus of the present discussion, foreign language (FL) education.

\section{Languages and Nationing}

What globalization is undermining is an extended effort of states to align social, political, and geographic space - essentially national territory - with a consolidated language (i.e., internally directed toward a standard literate universally acquired form), a process sociolinguist Joshua Fishman (1972) has dubbed nationing. In his earliest reflections on language and nationalism, Fishman identified three critical functions that languages serve in nationing activity: producing efficient administration, invoking cultural authenticity, and promoting unification politics (Fishman, 1972).

Over time, these constructed functions have been rendered natural and normalized by practically universal application (Seton-Watson, 1977, 1981). Elie Kedourie's (1961) early formulation of this activity of making language symmetrical with nation stresses both its construction and the constructors. In this formulation, languages are nationed by raw political power: "[l]t is absurd to think that professors of linguistics and collectors of folklore can do the work of statesmen and soldiers" ( $p$. 125). Teachers and writers in the professional roles, and parents as ordinary citizens in the language socialization of children, do contribute to nationing by converting political choices of statesmen and soldiers into cultural forms, which then circulate among all citizens. In this complex collaboration, an essentially political and nation-centered practice of language politics is tied to the routine daily activity of educators, parents, and ordinary administrators. In its early phases, language-based nationing addresses communication practices of existing citizens, but over time nationing expands beyond its political borders, whether through imperialism or the attraction of foreigners through cultural soft power (Nye, 2004). This conversion of a nation's domestic language choices into foreign language study programs abroad is formalized in the cultural promotion policies of states. Nationing is also extended through the teaching of official state languages to new immigrants. Hence three new categories of learners are acquired for national codes: the foreign colonized, through imposition; the admitted immigrant, through necessity; and foreigners attracted by the prestige and culture of the admired language, through voluntary choice. All constitute a process of extended nationing (Lo Bianco, 2005). Hence we have three kinds of language nationing: vertical effects as the young of a nation grow into citizenship, horizontal effects as newcomers are admitted into citizenship, and extra-national effects through processes of FL study and imposition of national languages in political colonization.

Teachers are central protagonists of these activities and FL teachers its external ambassadors and representatives. Internal processes of nationing involve consolidating diverse dialects into more or less standard forms and confining rival language codes to domestic, rural, or private domains, reserving authoritative institutions and domains of state for the privileged national code. In this way, the linguistic behavior of a society becomes exclusive and excluding within national boundaries, and by mirror reasoning constitutes extra-national political territory as foreign. The internal process of linguistic consolidation in foreign settings produces standard and foreign languages in those settings, so that languages symbolize geographic and political space. The apex of this process is the conferral of unique national names to linguistic codes, so that languages name nations and pure symmetry is cast between the two: In Russia, Russians speak Russian, in Japan, Japanese speak Japanese, and in 
France, the French speak French. However, in few settings have these longue durée processes of language planning been free of ambiguities, contradictions, or brutality, and in many cases they are characterized by incompleteness or outright failure, giving rise to unassimilated minority language communities, often with historical grievances (Calvet, 1998).

\section{Globalization: migration, networks, and technology}

In detailed documentation and classification of population mobility, Castles and Miller (2009) emphasize the multifarious forms of human movement that characterize contemporary globalization. From their analysis it is clear that, over the past four decades, the directions of migration movement, the duration of population shifts, and the participants involved in human mobility have all expanded. Today vastly greater numbers of people move than ever before: legally, semi-legally, and illegally; in all directions and from all directions; in many diverse social configurations: male-led and female-led, individual and family, chain groups or sub-national minority dominated; for varying durations: longer, shorter, permanent, or itinerant stays; and for increasing numbers of purposes: study and credentialing, settlement, romance, tourism, recreation, and crime. Nostalgia, memory, recreation, assimilation, or return are all nurtured in the increasingly individualized experiences of those who move.

This vast population mobility has converted most countries of the world into plural societies, so that the experience of community-level multiculturalism and multilingualism is now itself universalized. This is most dramatically true among traditional countries of emigration, such as Ireland, Italy, Greece, and Japan, which have been transformed into countries of immigration. In just one or two generations, such societies have changed from shedding large proportions of their working-age demography to hosting employment- and refuge-seeking multiethnic immigrants, and now increasingly struggle with the co-existence of multiple languages, faiths, and ethnicities, demands for which they are unprepared.

These kinds of diversity challenge the founding discourses of many nations, especially those that claim a single unifying and culturally authentic language and either a single faith tradition or a dominant one. Such pluralization is experienced in different ways according to the particular legal frameworks of the host society, the precise nature of the migration type, as explained by Castles and Miller (2009), and the political preparedness and cultural attitudes of the host society toward diversity. Host societies also differ according to the level and depth of domestic resistance to processes of migration-induced pluralization. Galloping pluralization due to population movements is extended further by the networks formed by new arrivals and hosts alike, so that disparate parts of the world are linked in instantaneous and multi-modal communication, allowing individuals residing in practically any setting to maintain constant and mostly private connection with places of origin or places of interest.

Most new immigrants settle in urban zones, and so this subtle scrambling of what is here and what is now turns modern cities into vast incubators of identity, zones where it is possible to live here but identify with away from here, live now but memorialize the past and inhabit its absent patterns in the present. Cities, more than any other human agglomeration, host networks of interacting communication which are more in tune with extra-national counterparts, i.e., interlocutors in other cities, than with their own national hinterlands in new geographies of identity (Bell \& de-Shalit, 2011).

Alongside the migration aspect of globalization and the global interconnectedness of the world's cities, pluralization is a result of the information age. Sociologist Manuel Castells $(1996,1997,1998)$ has documented the rise of the information age in a trilogy of works dedicated to mapping and describing concrete technological and organizational linkages of communication. In recent work (Castells, 2009), he has synthesized this mapping of information flows and their technological supports into an 
extended analysis of the cognitive, emotive, and identity consequences of networks, of the power and potential of this horizontal flow of information and organization. Networks are relatively difficult for state authorities to regulate and control, and therefore they develop the propensity to destabilize national authority, norms, and structures.

Networks can be national as well as international, and conservative and arresting of change as much as they are subversive and transgressive, but it is the latter feature - that is, the way in which international and affinity networks subvert national controls and culture - that dominates how civil society and nonstate networks are perceived and researched. This is clear in the analysis of the wave of revolutionary political protest and upheaval occurring in many Arab countries since December 2010. Swift and effective deployment of social media during the so-called Arab Spring has permitted new kinds of political mobilization, forging horizontally organized chains of synchronizing action. Extensively documented by communication researchers (K. Taylor, 2011), social media are both information infrastructure and tools, but also shared values and behaviors (Howard \& Parks, 2012). More recently, since February 2013, we have seen the rise of civic politicians in Italy, under the aegis of Cinque Stelle - the 'Five Star Movement' - forging a new public and radical form of integrated virtual mobilization, combining blog and continuous live video feeds tied to regular online plebiscites. This 24/7 continuous debate mode of politics is exposing mainstream political parties to direct and intense public scrutiny, forcing them to adapt to network technologies. Celebrated as liquid democracy or globalization-produced web democracy by its mainly young insiders, to opponents it is mere populism, or even anti-politics, aiming to subvert the power of traditional political interests, and criticized for being anarchic and refusing to offer an alternative order (Serafini, 2012). The language of these web democrats is saturated with all the familiar digital discourse, a dialect of English vocabulary, discourse patterns, and acronyms.

State and corporate suppression and manipulation of social media is as probable as its liberatory or emancipatory potential in the hands of rebellious masses. However, social media remain emblematic of disturbance to established practices of public decision making and tend to destabilize established social norms, developments that many welcome as opening up possibilities of "flexible citizenship" (Ong,1999, p.3) and the "nomadic subject" (Ong,1999, p.124) within a wider reality of transnationality. Social media politicians and activists are a phenomenon of interconnectedness, and tools that are the preconditions of their work are accessible communication technologies, with a significant presence of English-loaded messaging, broadcasting and narrowcasting simultaneously. The ability of social media to effect cultural change increasingly unbounded by nation-state interests is unprecedented in history and itself a factor in globalization (Howard \& Parks, 2012).

The age of globalization is thus an age of migration, information, and new kinds of mobilization. This vast and accumulating complexity involves simultaneous change in multiple fields, and leads to what Giddens (2003) has called a runaway world. In Giddens's depiction, globalization, localization, and regionalization produce each other. Social groups might stress locality and tradition against homogenizing pressures from outside, while the logic of cost efficiency and of neoliberal and technological standardization produce world systems and contest small markets and local orientations. Regionalization is proposed as an intermediary or compromise form of political structure, or as an alliance against excessive localization or dominating globalization. We can see this in the European Union where the traditional nation-states of the continent see closer union as a defence against the trading power of China, India, and the United States, and at the same time subnational regions increasingly assert their identity, sometimes in cross-border alliances that recover older pre-nationstate identities. 


\section{Globalization makes local connections to external powers salient}

A clear effect of globalization on language study can be seen in the account of Chinese language learning in the United States (Wang, 2007). In her analysis, Wang identifies diverse forms of social capital that knowledge of Chinese supplies to learners, according to how they are positioned in relation to the Chinese state, its diverse cultures, and historic civilization. The many U.S. providers of Chinese learning opportunities mediate between students and particular interpretations of China and Chinese knowledge. The various layers of identity relationship with things Chinese include the linguistic (dialect, regional standards, national standard, classical) and the main orthographic forms; the national (citizenship, homelands, diasporas) and several, often incompatible, political, and historical allegiances. Globalization's consequences for languages extend across the full range of what count as languages, their status, their corpus and discourse forms, their spatial and sociological distribution, and cultural and ideological aspects. Recent scholarship has focused on new modes of work available through global communication networks, with interlocutors drawn from beyond predictable speakers of past times, and effects of language commodification and exchange in the new economy (Duchêne \& Heller, 2011; Tan \& Rubdy, 2008). Globalization also produces intra-linguistic communication effects (Block \& Cameron, 2002) often evident in widespread adoption of English terminology and in codeswitching into English. The cultural consequences can be seen as local instantiations (Risager, 2006) of global patterns, making it difficult to determine the national and the foreign in the cultural apparatus of a communication system. The commercial effects are evident in the burgeoning demand for learning Chinese.

We can see readily that languages are implicated in all aspects of the flux produced by globalization, most evidently the increasing use of English in education and the media. Dramatically bringing both of these together was a front page declaration by an important French newspaper, Libération, contesting that nation's 1994 Toubon Law, which restricts the use of foreign languages in classrooms. In an attempt to attract a greater share of the international fee paying student market to France, proposals have been made to modify the Toubon rules to permit courses in English, which Libération welcomed with a full page one editorial on 21 May 2013: "Teaching in English. LETS DO IT." The newspaper describes English not as the language of unbridled capitalism that critics and readers of the particular newspaper might decry, but as the language of Shakespeare, suggesting that, in particular social strata, foreign has never really meant unfamiliar. Ostler's (2005) language-focused history of empire, expansion, and past globalizations underscores this point, which we should consider a caution against seeing today's economic-centered globalization as the sole experience of globalization.

What is occurring with French universities enjoined to teach in English disrupts the practices of universities required to teach in national languages. However, prior to the existence of nations and national languages (and indeed of universities construed as national institutions), Western academies of higher learning functioned for centuries in a supra-national form, using a convenient international tool of communication, Latin, as did universities in the Islamic world with Arabic (Lo Bianco, 2010a). In India since antiquity, Buddhist-centered institutions such as Nalanda and Taxila provided higher education for students drawn from a vast arc of the world, today constituted as separate nations.

Reflection on these inheritances from a longer past underscores the claim that globalization today is not unprecedented, and in fact continues a long history of intercultural contact and prior experiences of global interaction, with common literary and scientific languages in research and higher scholarship existing for millennia (Ostler, 2005, 2007). Early globalization was disrupted by the practices of nationing and contemporary economic globalization may be fostering a return to some features of the pre-national world. 


\section{Globalization and some aspects of what is foreign about foreign languages}

How are teachers, policymakers, and curriculum planners to organize the field of languages in light of contemporary globalization? A key question to address is which foreign languages English speaking countries will choose to have their children learn. How is selection to be done? Realist political analysis (Bell, 2011), as distinct from normative or idealist political philosophizing, pays attention to world events and material power. In this spirit, Cha and Ham (2008) have explored foreign language selection, specifically comparing English, French, German, Russian, and Spanish between 1850 and 2005 , surveying 15 countries in the first period of years and 154 in the latest period. They find language choice to be closely tied to world events. The period of time they review coincides with the beginnings of compulsory education and of centrally organized school systems with established curricula, right up to the full onset of today's globalization. The outcome of major political and military events, and of technological and economic developments, appears determinative of the fate of the national languages taught in the countries involved.

The researchers find that the preeminence of German universities, industrial science, and efficient state mechanisms made German the first FL of choice in the 15 countries they survey for 1850 . This was progressively eroded with Germany's defeat in the first, and humiliation in the second, of the two great wars of the early 20th century. Their data show that after 1919, German ceded to French and English in roughly equal measure, and after 1945 completely to English (with French partially ceding to English also). Russian established a toehold presence during the Soviet era and language preferences were patterned according to Cold War allegiances and geopolitical calculations, as well as traditional literary and cultural prestige. This pattern prevailed until 1989 when the collapse of Eastern European communism saw English replace Russian, consolidating its functional utility worldwide and eroding the curriculum presence of French. The new communication order implicated in Asia-century discourse is essentially a continuation of this language competition triggered by world events, from English to World Englishes, to vast new presence and claims made on behalf of modern standard Chinese (Lo Bianco, 2007; Tsung \& Cruickshank, 2011). While Chinese has established a strong presence among FL preferences, there is no evidence it is displacing English. Instead, in Southeast Asia and in China itself, English has strengthened (Adamson, 2002; Kirkpatrick, 2012), and in settings in which neither English nor Chinese is the primary social language, English retains first FL priority, with Chinese occasionally ranking second (Cha \& Ham, 2008). The world events effects, essentially effects of economic globalization, mean that in English speaking countries, as seen from nonnative English speaking perspectives (Byram et al., 2010), FL choices have become diversified. As a result, there is a bifurcation in globalization's impact on language choices: hyper-utilitarian demand for English in non-English speaking countries (with smaller effects of utilitarian demand for German in China and French in Africa), and mostly low-utilitarian demand for foreign languages in English speaking countries. Partial exceptions to this pattern include demand for Spanish in the United States, because of continually replenished Spanish-speaking migration, and Chinese in Australia, Canada, and the United States. Hyper-utilitarian demand for English tends to restrict FL offerings in nonEnglish speaking countries, and removes much of the utilitarian reasoning for FLs in English speaking countries. The general effect is narrowed FL choices in non-English speaking countries and widened FL choices in English speaking countries. In recent decades in all Anglophone settings, language learning choices have expanded to include heritage languages, commercially relevant Asian languages, especially Chinese and Japanese, but also Arabic, alongside traditional foreign languages of culture and literary prestige, but overall rates of study and retention have declined.

\section{Calculating language power in globalized markets}

In keeping with the realist tradition, De Swaan's (1993) Q-value method, which measures the communication potential of a language for a speaker in a given communication system, is a 
systematic calculation of the relative power of different languages. Q-value calculates how individuals add to their linguistic repertoire. They do this in a process akin to self-investment, by studying those languages that promise the greatest communication payoff, or, in economic terms, the greatest return on their investment of time and effort. In this way, an individual acts like a personal economy, calculating how to increase his or her marketable personal quotient of Q-value to deploy in the labor market. Because of its powerful constellation of geographic spread, institutional presence, and technological and human resources, English is well-endowed with Q-value. Phillips on (2004) subjects De Swaan's system to a scathing critique for ignoring the genesis and means by which English has attained this felicitous standing, namely linguistic imperialism, and for neglecting to consider the negative effects of English as a medium of instruction and the rights of learners to pursue education in their native language. He argues that De Swaan's method imagines that the world language order is culturally neutral, and that Q-value is calculated with abstract and impersonal operations, as if the language order of the world were removed from interests and power. De Swaan (2004) repudiates what he decries as "linguistic sentimentalism" (p. 573), defending his classification as a simply realist acceptance that marketplaces of exchange govern language preferences, and declares rights based arguments irrelevant to the language behavior of individuals.

A critical perspective on such market based reasoning, specifically examining higher education in South Korea, is the article "Neo-liberalism as language policy," by Piller and Chao (2013). The authors critique the operation of university rankings and their underlying logic of a unified competitive marketplace for competence and its credentials. Though it does not mention De Swaan and Q-value rankings of languages, their study traverses closely related ideas and practices, especially the competitive ranking of universities, and the repercussions these have on the policies of language of instruction. According to Piller and Chao, South Korea's responses to the interlinked globalized university system include reliance on a neoliberal economic ideology that functions as covert language policy promoting the adoption of English, with deleterious effects on learners and education systems. This is an additional installment in the politics of language under conditions of economically determined globalization, exposing incompatible modalities of reasoning about the value of language, transferring into sociolinguistic calculations the Anglosphere logic of homo economicus previously discussed.

Neoliberal reasoning transfers to language the full logic of the market, which, as philosopher Charles Taylor (2004) shows, completes a process of creation of the modern social imaginary in Western society. In Taylor's historiography and textual depiction, three cultural forms have structured the moral order of Western political life since the Middle Ages: the economy, the notion of what is public or shared space, and self-governance. In Taylor's depiction, Western modernity is characterized by a distinction between two entities he calls "the social imaginary" and "the moral order" (p. 2), the latter concerned with norms and concepts of behavior and the former relating to cultural phenomena of practices, shared knowledge, social understandings, and expectations, all of which operate to forge social living, and that take the forms of sovereignty, especially popular forms of political life, the economy, and public space. Taylor's work discusses Western pathways to the modern, which in this view originate in the late Middle Ages as a distinctive moral order resulting in the idea of politics as servant of human needs, happiness, improved life chances, and of diverse kinds of equality. According to this analysis, modernity in the West has developed in such a way that a notion of economics lies at the core of citizen self-understanding, seen as rational, and implying an obligation on political life.

Walter Mignolo (2011) transfers attention from Old World historiography to New World history, conducting a critique of Western modernity less concerned with how economistic logic emerged than with its global reach and imperial expansion, whether directly in European hands or by North American proxy. Under globalization and indigenous resistance to its incursions, Mignolo holds that today's global interconnectedness has achieved an irreversible momentum toward poly-centricity, toward what 
he has often called a pluriverse. Under such conditions, Euro-American modernity can no longer function normatively, in its semiotic practices, its literacy, its forms of knowledge and social order, as it has done since the European Renaissance and the colonial expansionism that followed new-found self confidence among European states. Mignolo's project of undermining colonial legacies is premised on constructing a contesting decolonial epistemology that responds to locality as lived reality and memory, tradition, languages, texts, and indigenous knowledges particular to pre-colonial life, especially in the Latin American world, the main locus of his work. Decolonial logic emerges from Mignolo's critique of the unitary knowledge systems that provincialized indigenous knowledge forms and social practices or, in Taylor's terms, moral orders. In earlier work, Mignolo (2003) had focused on literature, formal historical analysis, map-making, and language as a collective apparatus of normalizing and making authoritative Western knowledge systems into projects of colonial domination.

In a more limited claim, but critical for the argument of this article, Blommaert (2010) contends that globalization poses the challenge of full disciplinary dissolution for sociolinguistics. This analytical framework for comprehending relations between language and society implies for Blommaert deep conceptual limitations, since sociolinguistics as currently conceived relies on regularity of relations between linguistic and social phenomena. This variational sociolinguistics sees variation in language form correlating with specific places, social categories, roles, genders, and ethnicities, in what are taken to be stable resident communities who imagine themselves as nationalities or national states. Using evidence from African and immigrant/refugee populations in contemporary Europe, Blommaert exposes serious limitations in the explanatory categories of traditional sociolinguistics. Even the fact that the entities to which sociolinguistics has tied its analysis (i.e., human identity categories like social class, profession, gender, ethnicity, and sexuality), have become multiplied under globalization, does not satisfy Blommaert's radical assertion. His claim that language itself is intrinsically and permanently in motion leads to a new lens for its description, a "sociolinguistics of mobility" (p. 5), in which motion, both temporal and spatial, is located at the center of the conceptual framework required to comprehend contemporary language. A sociolinguistics of mobility requires seeing language as fully constituted by mobile resources, transcontextual networks, flows and movements. This new kind of language lives not so much in villages produced by globalization as in networks of villages and other kinds of human living connected with each other in ways that are themselves always in flux. If standardized national languages carry the names of nations and historically assist in the process of their constitution, then dissolving the fixity of these languages implies challenges to the national states they denote and index.

Mignolo and Blommaert collectively see the consequences of globalization at the heart of the meaning-making systems we call languages and the privileges accorded to a selected few over the many. Further, Mignolo and Blommaert locate globalization's challenge at the very center of the practices of cultivation, policy and teaching of languages of privilege, and therefore to the institutions within Western and Westernized nation-states that have sustained these privileged codes for centuries.

The argument of the present article has a more modest aim, namely, to scramble the nation-language connection in foreign language education, both in relation to the culture that foreign language is taken to represent, and also to the foreignness of both the language and the culture. The more radical undoing of the scholarly understanding of language itself, as discussed by Mignolo, and of sociolinguistics, as argued by Blommaert, among others, substantially supports this, since a multiplying number of social forces is dislodging languages from their permanent association with stable and resident communities, especially homogenous unilingual states with uncontested national languages. 


\section{Globalization and language categorization}

This line of questioning of globalization's repercussions for foreign language education concerns the classification and categories of languages available for inclusion in public education programs, a kind of policy ontology. We can begin by distinguishing between various categories of languages and discussing the implications of the nomenclature used and how these appear in policy.

First, we can distinguish between the living and the dead. The latter are typically called classical languages in educational contexts. The hold of the classical tradition weakened very slowly in Anglophone settings. The immensely long duration of Latin is instructive in the context of the global wars of language today (Calvet, 1998; Ostler, 2007) and Latin remains unique in historical longevity as an extra-national language. Its presence as a language of pedagogy, science, and cross-border convenience (i.e., a lingua franca) exceeded its political and military power by some 1,200 years (Ostler, 2007), so that, to use contemporary language, Latin's soft power endured this much longer than the hard power of the Roman Empire that had sustained it for a millennium prior to 476. In that year, a Germanic soldier named Flavius Odoacer deposed the last Western Emperor, Romulus, crowned himself King of Italy, and brought the Western Roman Empire officially to its military and political end (Ostler, 2007; Lo Bianco, 2010a). It cast Byzantium, the Eastern Roman Empire that lasted another millennium, as a progressively Greek- speaking polity (Brownworth, 2009).

This extraordinary longevity as a language of elite culture and of scientific literature conferred on Latin a large part of its standing in education through much of the 19th to the middle of the 20th century. The pedagogical preference in all classical language teaching, Classical Chinese and Sanskrit just as much as Ancient Greek and Latin, has been the formal study of canonical texts, explicit learning of formal grammar, translation exercises, and model structures and genres emulated in writing. In its Western manifestation, both the pedagogy and its purposes, such as study of exemplar models of expression and literature selected because they provided moral inculcation as much as intellectual rigor, and exposed learners to formative experiences of the Western intellectual inheritance, were perceived to be under threat from multiculturalism in the United States in the 1980s. The principal champion of the classical inheritance was E. D. Hirsch, who vigorously defended traditional education and its languages against what he saw as declining standards of cultural knowledge. Hirsch (1988) famously railed against the relativism he saw in multiculturalism, which sought to have immigrant and indigenous languages and literatures taught in schools and nonstandard Englishes and nontextual genres of English expression given recognition in literacy teaching. In defence of the English literary canon and prestige foreign languages, Hirsch argued: "Linguistic pluralism enormously increases cultural fragmentation, civil antagonism, illiteracy, and economic-technological ineffectualness" (p. 91).

The ferocity of the arguments about standards that characterized public education in this period was an early warning shot of the deep repercussions of globalization on the entire language education enterprise, with the purposes and contexts of teaching in an increasingly interconnected world colliding in the choices that curriculum policy was required to make. In language education contexts, however, the challenge to the traditional foreign languages of the curriculum from the bottom up, that is, immigrant and indigenous languages of heritage value to speakers, mirrored the previous shift in the foreign language order, when classical languages were replaced by what came to be called modern languages. Initially the designation modern meant living languages. In due course, the category modern languages was, rather more rapidly than occurred for the destabilization of classical languages, itself undermined by a key assumption of modern languages, and a key focus of this article, the idea of spatial distribution of languages.

Classical languages were neither here nor now, neither present temporally nor spatially in the learner's world, whereas modern languages were justified as being (potentially at least) available to learners, so the purposes of teaching came to include knowledge of contemporary spoken varieties. They 
remained foreign in their geographic distribution, so their availability was only in texts and in the input provided by teachers. Classical languages were doubly displaced, that is, present only in past times and other places. Hence travel was required for direct encounter with representative speakers, who were available natives of the language, but physically absent from the learner's immediate world. A language such as this could only make limited and intermittent impact on the direct world inhabited by learners, and therefore on the assumptions and design of the curriculum for the teaching of culture, which would accompany the teaching of language. With the population mobility that has accompanied economic globalization, and the concomitant emergence of real time instantaneous communications, much of this particular operating assumption of the traditional design of modern FL teaching has been eroded.

For some institutions, the university in particular, a central feature of globalization (Altbach, 2004) is internationalization of the student body, in effect reproducing the original pre-national form of the university, Europe's medieval university as a supranational entity with a common transnational language (Lo Bianco, 2010a). For schools, curriculum design needed rapidly to adjust to the presence of large numbers of learners from diverse cultural, religious and language backgrounds, and in this respect Australian, British, and U.S. experiences diverge.

Curriculum effects of the post-1947 migration program that transformed the population of Australia were being felt by the early 1970s, and were especially pronounced in educational language politics. The key site for migration-based language advocacy was agitation for replacement of foreign languages with community languages, precisely because the latter were both modern (in the binary between classical and modern) and not foreign, that is, not alien to the sociological world of the learner (Lo Bianco \& Slaughter, 2009). The essential points of distinction between community and foreign languages can be discerned by looking back over the arguments posed for their inclusion in curricula. Community languages typically have local institutional presence, with domains for use in the accessible, direct, and immediate world of the learner; they typically generate and use local norms of expression and so become linguistically distinguishable from their homeland standards, often fossilizing original forms, often hybridizing locally by adapting to host language vocabulary and context. Community languages can be characterized through discourse practices such as particular kinds of codeswitching, bilingual humour, and nuance in which the host environment realia and experience feature. Finally, community languages generate a discourse of normalization and value. While the speakers can experience ridicule or rejection by home country representatives, they often react to these by stressing the bilingual context of their new linguistic ecology and the new identities associated with the host environment. In several countries hosting large numbers of new immigrants, a movement adding the qualifier community to geographically present languages arose during the 1970s, the new naming being part of agitation and advocacy for including these languages in curricula traditionally preserved for prestige foreign languages.

In Britain, modern languages had often been called modern foreign to distinguish them from home country or indigenous languages (e.g., Welsh); immigrant languages were included in this classification since the term Community languages (with capital $\mathrm{C}$ community) was already current as a distinguishing term for the official languages of the European Community. Britain's mid-1970s accession to the then European Economic Community changed modern FL education by the required inclusion of Community languages (i.e., the official national languages of other EEC Member States) among its educational offerings. We see here the operation of the supranational, as distinct from the extra- or international realm, due to the sovereignty pooling of the European unification process, as a source of policy influence from globalizing processes not available to either Australia or the United States.

Cornish, Welsh, Scottish Gaelic, and Irish are usually identified as indigenous or home country languages, while in Australia and North America the large number of precolonial languages have 
experienced several phases of agitation for recognition and are variously labeled indigenous or Indigenous, Native American, Native, First Nations, Aboriginal, or occasionally in Australia, Australian languages. Nomenclature battles have been waged over the decades in line with struggles for civil rights in education and more generally, with key points in Australia being a 1967 referendum on Aboriginal rights, and in the United States the 1964 Civil Rights Act.

This proliferating set of categorizations, and the various modes in which they come onto the agenda of education authorities (bottom-up from citizen agitation, sideways in supranational agreements, topdown in imposed laws) expanded further when in the United States in the 1990s the term heritage language assumed discursive power. Essentially the equivalent of community languages in Australia, the category of heritage languages involved more than teaching presently existing languages, because it implies efforts at revitalization of languages whose speaker population has shifted to English, and, unlike Australia, included native or indigenous speakers.

This broad sequence from classical to modern (foreign) to community (heritage) had major and direct consequences for the pedagogical practices suited to each category of language. Modern and foreign languages had typically been taught in secondary schools. Community and heritage languages often were confined to the elementary school level, and were taught in various kinds of bilingual mode, that is, used as media of instruction, mostly transitionally. It was not until the emergence of content-based instruction (CBI) in the United States during the 1980s (Brinton, Snow, \& Wesche, 1989), and content and language integrated learning (CLIL) in the mid-1990s in Europe (Coyle, Hood, \& Marsh, 2010), that this mode of teaching became widely established for modern/foreign languages.

The cultural content that would be included in the teaching of languages from different categories tends to vary considerably. In classical languages the content of culture was validated and selected on the basis of its canonical status and for its ability, in the case of Latin, to illuminate historical and contemporary parts of English vocabulary, style, and even linguistic analysis, since grammatical description itself owed a great deal to the classical tradition.

Modern, foreign, and modern foreign languages relied on notions of literary and cultural prestige for their presence in the curriculum, in similar but less text-dependent ways than classical languages, other than languages introduced for strategic and geopolitical reasons, whose purposes and therefore content stressed spoken language effectiveness.

In Table 1, I depict these two notions of educational linguistics, the first as organized in the 1970s and the second as transformed into the pattern shown.

The national was devoted totally to English, the extra national marked as foreign and divided according to indicators of prestige or strategic importance, the sub-national language was typically constituted of a heterogeneous grouping of indigenous and other forms of speech (social and regional dialects of the national language not elevated for inclusion in the curriculum), and community languages, both categories - the indigenous and the community - in various states of shift and vitality and standardization.

Because this shift in language offerings arises from the prior shift of the speaker populations through migration, it is a consequence of globalization. Because these speakers make local demands for languages that were once foreign or absent to the local institutional setting, but that are now part of the local communication environment, learners encounter the language locally, further distinguishing them from fully foreign traditional languages (see Lo Bianco \& Kreeft Peyton, 2014).

The foregoing has aimed to show how in English speaking settings the languages taught in schools are, as a result of globalization processes, more diverse in number and kind (i.e., traditional languages 
of literacy prestige and also immigrant and indigenous heritage languages). The next section discusses how globalization has impacted English, making it less foreign even in non-English settings.

\section{TABLE 1}

Two Notions of Educational Linguistics

\begin{tabular}{|c|c|c|c|c|}
\hline & NATIONAL & EXTRA-NATIONAL & SUB-NATIONAL & EXTRA-TEMPORAL \\
\hline 1970s > & English + & $\begin{array}{c}\mathrm{FL}+ \\
(+ \text { living + prestige + } \\
\text { strategic + distant })\end{array}$ & $\mathrm{N} / \mathrm{A}$ & $\frac{\text { Classical }}{(+ \text { prestige }+ \text { dead })}$ \\
\hline Transformed > & English + & $\begin{array}{c}\underline{\mathrm{FL}}+ \\
(+ \text { living }+/- \text { prestige }+ \\
\text { strategic - distant })\end{array}$ & $\begin{array}{c}\underline{\mathrm{CL} / \mathrm{HL}+}+ \\
(+ \text { living }+ \text { local }+ \text { - prestige })\end{array}$ & $\frac{\text { Classical }}{(+/- \text { prestige }}+$ dead $)$ \\
\hline
\end{tabular}

Note. $\mathrm{FL}=$ foreign language; $\mathrm{CL}=$ Classical language $; \mathrm{HL}=$ heritage language .

\section{English as a basic skills under globalization}

In June 2006, during a visit to Beijing, China, I interviewed an official in the Chinese ministry of education about foreign language education in China. I was curious to better understand what I had read in curriculum documents, to explore the ministry's policy, objectives, and support for different foreign languages, and to compare this to the promotion of Chinese abroad. These questions were part of an overall research project between the University of Melbourne Faculty of Education and Beijing University Faculty of English, which was eventually published under the title "China and English: Globalization and Dilemmas of Identity" (Lo Bianco, Orton, \& Gao, 2009).

The official was explaining how support for foreign languages was organized and he produced an organization chart, replete with boxes, dotted lines, and arrows. As I studied this I could identify several languages in one box labeled 'Foreign Language Education,' including Japanese, French, German, and Spanish, but not English. When I asked about this apparent anomaly, the official pointed to another part of the ministry chart and replied: "English? ... English here! English not like foreign language. English for everybody."

A 2007 review of the state of English in the world entitled "English Next," and produced for the British Council by David Graddol (2007), carries the suggestive or possibly provocative subtitle "Why global English may mean the end of 'English as a Foreign Language'." Several times in this document the author describes acquisition of English as a basic skill. For example, on page 15 he makes the following forecast:

The competitive advantage which English has historically provided its acquirers (personally, organisationally, and nationally) will ebb away as English becomes a near-universal basic skill. The need to maintain the advantage by moving beyond English will be felt more acutely. ( $p$. 15)

and later: "[T]he learning of English appears to be losing its separate identity as a discipline and merging with general education" (p. 102). This argument, that English is increasingly regarded as a component of basic education rather than as a part of foreign languages, was effectively what the 
ministry official performed in our meeting.

In the highly influential work of Nobel laureate James Heckman (2000), literacy skills are shown to be the basis of diverse forms of human capital.

Throughout his writings, Heckman describes a process in which literacy is a generative skill "begetting" other skills, (Heckman, 2000, cf. p. 50). This generative view of literacy opens the field of languages to similar kinds of human capital and economic reasoning under the rubric of generic skills. This is clear in David Graddol's (2007) analysis of English as a world language, especially in primary schools, where it is used to

acquire new knowledge and specialist skills in the future: learning how to learn. Literacy in the national language and, perhaps the mother tongue where that is different, remains a basic skill, as does numeracy. But information technology - how to use computers and applications such as word processors, spread sheets and internet browsers - has become just as important in basic education. In globalised economies, English seems to have joined this list of basic skills. Quite simply, its function and place in the curriculum is no longer that of 'foreign language' and this is bringing about profound changes in who is learning English, their motives for learning it and their needs as learners. (p. 72)

This quote distills the evolution of one of the earlier arguments about the impact of globalization on language education, at least specifically with regard to English, the underlying reasoning about the purposes of education itself, and therefore the increasingly globally shared rationality of education for human capital formation, within which foreign languages have been admit- ted. Here we can foresee the battleground that will face foreign language education for the immediate future: the contest of value between those wishing to wrest language education from its construction as a tool of narrowly conceived economic interests, to defend a rival vision of humanistic, cultural, and intellectual goals, and those wishing to consolidate the utilitarian reasoning of much contemporary language education, with its bias toward a world auxiliary English and a small number of other international languages. Much of this battle will recall the two orders of the formation of Western modernity, the social imaginary formed by utilitarian relations between citizens and politics, and a wider moral order of difference.

\section{Domesticating the foreign}

Globalization has brought the physical presence of most outsiders, represented by their languages and cultural practices, inside states whose past language nationing had sought to make exclusively unilingual. The reasoning behind curriculum policy and much educational practice is challenged to reimagine public space in multilingual and multicultural ways, interacting and co-located, and yet still connected to homelands and spaces of authenticity and origin. This complex characteristic of the ages of migration, networks, agitation, hybridity, and co-habitation, all fused in shared civic space, demands extended interaction between professionals and applied linguists, teachers, and researchers, from the multiple language categories that claim presence in the curriculum. Foreign language education therefore needs to engage in assumption-dissolving conversations with heritage, community, indigenous, and English language educators to forge a principled depiction of what is shared and what is distinctive. Yet professional associations, academic journals, and the subdisciplines among language educators are specialized and hardly interacting. Bilingual/multilingual contexts, with worldspreading English, appear to be the inexorable language ecology within which foreign language education occurs, and conversations grounded on those new realities that have been advocated in recent years, emphatically in the Special Issue of the Modern Language Journal "Toward a Multilingual Approach in the Study of Multilingualism in School Contexts" (MLJ, 95, 3). 
Language educators are often barricaded behind walls of professional identity. Foreign language teachers have worked with the operating assumption that the locus of their professional interest, usually a standardized national official language of literary prestige, is located in a foreign place. Heritage and community language professionals have operated with assumptions that the physical locations of the languages of their professional concern are locally present. These languages are physically and institutionally close to the learner, his or her home and therefore to the teacher and his or her location of professional activity. It is this proximity, with its cognitive as well as its emotive and sociological realities, that motivates professionals to advocate for inclusion of these languages in public education.

For advocates of classical foreign languages, the objects of their attention are distant in both time and place, and this otherness, and its formative influence on our present-day cultural values and knowledge, is sufficient warrant for their inclusion in education. Many aspects of the networks, practices, and goods produced by and exchanged in globalization are mediated by English and a substantive discussion of globalization itself, and its effects on languages, requires serious study of the role of English in the new kind of human metropolis being constructed in the interactions of contemporary life.

New moorings, and deeper reflection on the new meanings of communication and of languages for the professional activity of language teachers of all kinds, are implicated by these processes of contemporary globalization. As a result, dialogue across the interests and professional categorizations of language education is urgently required: English teachers and researchers, foreign/heritage teachers and researchers, and teachers and researchers concerned with indigenous languages, all bring unique perspectives shaped differentially but equally by globalization.

Such a dialogue can foster deeper understanding of the different nature of the experience of domestication of communication that was once distant and unfamiliar, that is, foreign, a domestication that globalization has produced. A comprehensive professional dialogue can also stimulate new understanding of the place of languages in the lives of individuals, as the bounded national states that used to govern the spatial distribution of communication, speech, and writing, are increasingly scrambled, and with new technologies that are now multimodal and multigenre as well as multilingual. A new and dynamic approach to foreign language education, in the context of the communication effects of globalization, requires ongoing interrogation as it surrounds us with unprecedented challenges of conceptualization and still unimagined challenges of pedagogy.

\section{References}

Adamson, B. (2002). Barbarian as a foreign language: English in China's schools. World Englishes, $21,231-243$.

Altbach, P. (2004). Globalization and the university. Tertiary Education and Management, 10, 3-25.

Appadurai, A. (1996). Modernity at large: Cultural dimensions of globalization. Minneapolis, MN: University of Minnesota Press.

Bell, D. (2011). Introduction: Under an empty sky: Realism and political theory. In D. Bell (Ed.), Political thought and international relations: Variations on a realist theme (pp. 1-25). Oxford: Oxford University Press.

Bell, D. A., \& de-Shalit, A. (2011). The spirit of cities: Why the identity of a city matters in a global age. Princeton, NJ: Princeton University Press.

Block, D., \& Cameron, D. (2002). Globalization and language teaching. London: Routledge.

Blommaert, J. (2010). The sociolinguistics of globalization. Cambridge: Cambridge University Press.

Brownworth, L. (2009). Lost to the west. New York: Random House. 
Brinton, D., Snow, M., \& Wesche, M. (1989). Content-based second language instruction. New York: Newbury House.

Byram, M., Lapkin, S., Lo Bianco, J., Met, M., \& Scott, A. (2010). Fremdsprachendidaktik in englischsprachigen Landern [The didactics of foreign languages in English-speaking countries]. In W. Hallet \& F. Konigs (Eds.) Handbuch Fremdsprachendidaktik [Handbook of Foreign Language Didactics] (pp. 28-35). Velber: Friedrich Verlag, Klett/ Kallmeyer.

Calvet, L. J. (1998). Language wars and linguistic politics. New York: Oxford University Press.

Castells, M. (1996). The rise of the network society. Cambridge, MA: Blackwell.

Castells, M. (1997). The power of identity. Cambridge, MA: Blackwell.

Castells, M. (1998). End of millennium. Cambridge, MA: Blackwell.

Castells, M. (2009). Communication power. Oxford: Oxford University Press.

Castles, S., \& Miller, M. (2009). The age of migration; International population movements in the modern world (4th ed.) Basingstoke, UK: Palgrave Macmillan.

Cha, Y-K., \& Ham, S-H. (2008). The impact of English on the school curriculum. In B. Spolsky \& F. M. Hult (Eds.), Handbook of educational linguistics (pp. 313-327). Malden, MA: Blackwell.

Coyle, D., Hood, P., \& Marsh, D. (2010). CLIL: Content and language integrated learning. Cambridge: Cambridge University Press.

De Swaan, A. (1993). The evolving European language system. International Political Science Review, 14, 241-255.

De Swaan, A. (2004). Endangered languages, sociolinguistics, and linguistic sentimentalism. European Review, 12, 567-580.

Duchêne, A., \& Heller, M. (Eds.). (2011). Language in late capitalism: Pride and profit. London: Routledge.

Fishman, J. A. (1972). Language and nationalism: Two integrative essays. Rowley, MA: Newbury House.

Giddens, A. (2003). Runaway world: How globalization is re-shaping our lives. New York: Routledge.

Graddol, D. (2007). English next: Why global English may mean the end of "English as a Foreign Language". London: British Council.

Heckman, J. (2000). Policies to foster human capital. Research in Economics, 54, 3-56.

Held, D., McGrew, A., Goldblatt, D., \& Perraton, J. (1999). Global transformations. Stanford: Stanford University Press.

Hirsch, E. D. (1988). Cultural literacy: What every American needs to know. New York: Vintage.

Hopkins, A. (2002). Globalization in world history. London: Pimlico.

Howard, P., \& Parks, R. (2012). Social media and political change: Capacity, constraint, and consequence. Journal of Communication, 62, 359-362.

Kedourie, E. (1961). Nationalism (2nd ed.). London: Hutcheson.

Kirkpatrick, A. (2012). English as an Asian lingua franca. Journal of English as a Lingua Franca, 1, $121-140$.

Lo Bianco, J. (2005). Globalisation and national communities of communication. Language Problems and Language Planning, 29, 109-135.

Lo Bianco, J. (2007). Emergent China and Chinese. In J. Lo Bianco (Ed.), Language Policy, 6, S3S26.

Lo Bianco, J. (2010a). Globalization, universities and medium of instruction. In P. Peterson, E. Baker, \& B. McGaw (Eds.), International encyclopaedia of education, (Vol. 4) (pp. 201-208). Oxford: Elsevier.

Lo Bianco, J. (2010b). Language policy and planning. In N. Hornberger \& S. L. McKay (Eds.), Sociolinguistics and language education (pp. 143-176). Bristol, UK: Multilingual Matters.

Lo Bianco, J., \& Kreeft Peyton, J. (2014). Language vitality in the United States. Heritage Language Journal, 11.

Lo Bianco, J., Orton, J., \& Gao, Y. (Eds.). (2009). China and English: Globalisation and dilemmas of identity. Clevedon, UK: Multilingual Matters.

Lo Bianco, J., \& Slaughter, Y. (2009). Second languages and Australian schooling. Camberwell, VIC: 
Australian Council for Educational Research.

Mignolo, W. (2003). The darker side of the Renaissance: Literacy, territoriality, and colonization. Ann Arbor, Ml: University of Michigan Press.

Mignolo, W. (2011). The darker side of Western modernity: Global futures, decolonial options.

Durham, NC: Duke University Press.

Nye, J. S. (2004). Soft power. New York: Public Affairs.

Ong, A. (1999). Flexible citizenship: The cultural logics of transnationality. Durham, NC: Duke University Press.

Ostler, N. (2005). Empire of the word. London: Harper Collins.

Ostler, N. (2007). Ad infinitum: A biography of Latin. London: Harper Press.

Phillipson, R. (2004). English in globalization. Journal of Language, Identity and Education, 3, 73-84.

Piller, I., \& Chao, J. (2013). Neo-liberalism as language policy. Language in Society, 42, 23-44.

Risager, K. (2006). Language and culture. Clevedon, UK: Multilingual Matters.

Rosenberg, J. (2005). Globalization theory: A postmortem. International Politics, 42, 2-74.

Serafini, M. (2012, September 23). Grillo e la democrazia liquida: II dibattito è aperto. Farà bene al movimento? [Grillo and liquid democracy: The debate is open. Will it be good for the movement?].

Corriere della Sera. Accessed 16 February 2013 at http://www.corriere.it/ politica/12_settembre_23/grillo-liquid-feedback-democrazia-liquida-movimento-cinque-stelle_ 885a7416-057c-11e2-b23b-e7550ace117d.shtml

Seton-Watson, H. (1977). Nations and states: An enquiry into the origins of nations and the politics of nationalism. London: Methuen.

Seton-Watson, H. (1981). Language and national consciousness. Oxford: Oxford University Press.

Tan, P., \& Rubdy, R. (2008). Language as commodity. New York: Continuum.

Taylor, C. (2004). Modern social imaginaries. Durham, NC: Duke University Press.

Taylor, K. (2011, September 13). Arab Spring really was social media revolution. TG Daily. Accessed 5 July 2013 at http://www.tgdaily.com/software- features/58426-arab-spring-really-was-socialmedia- revolution

Tsung, L., \& Cruickshank, K. (2011). Teaching and learning Chinese in global context. New York: Continuum.

Wang, S. (2007). Building societal capital. Language Policy, 6, S27-S52. 


\section{University Library}

\section{- M M N E R VA A gateway to Melbourne's research publications}

Minerva Access is the Institutional Repository of The University of Melbourne

Author/s:

Lo Bianco, J

Title:

Domesticating the Foreign: Globalization's Effects on the Place/s of Languages

Date:

2014-03-01

Citation:

Lo Bianco, J. (2014). Domesticating the Foreign: Globalization's Effects on the Place/s of Languages. MODERN LANGUAGE JOURNAL, 98 (1), pp.312-325. https://doi.org/10.1111/ j.1540-4781.2014.12063.X.

Persistent Link:

http://hdl.handle.net/11343/112276 